\title{
THE PROVOCATION OF LEVINAS FOR FEMINISM ${ }^{1}$
}

\section{Stella Villarmea}

\section{University of Alcalá - Madrid}

\section{Introduction}

In recent years some feminists have proposed that Emmanuel Levinas' writings could provide feminism with interesting theoretical resources; Ainley (1988), Chalier (1982), Chanter (1988, 1995), O'Connor (1988). However, I would not rely on the beneficial effects of Levinas for feminism for the following two reasons. Firstly, because no direct application of what Levinas explicitly says about women would help women's emancipation. Secondly, because other more general aspects of his doctrine are too abstract to be useful for feminism as they stand. Thus to take advantage of his claims, feminism would need to endow them with specific content. The problem is that Levinas does not give us any specific direction as to how to interpret his theory in the light of feminist purposes. Insofar as any feminist application of these general aspects of his theory remains open, his theory does not assist us in inventing the future. Accordingly, I think that feminists should not be charmed by the prospects of Levinas' theory for feminism.

The structure of this paper is as follows. Firstly, I will introduce some aspects of Levinas' account which are important to review his reception within feminist circles. Then, in the core section of this paper, I will analyze his text 'And God Created Woman' (1977: 122--148), and show to what extent his view of women can be criticised as being traditional and patriarchal. ${ }^{2}$ Finally, I will deal with the relation between Levinas and feminism of difference, and reject that his theory can be effectively applied to move beyond the debate equality $v s$. difference. 


\section{The feminine as the Other}

Levinas aims to contest a whole tradition of western philosophy. For him, philosophy has traditionally interpreted its goal as the study of how an individual could achieve a single view of the world. Levinas disagrees entirely with this interpretation of philosophy. He rejects that the starting point of philosophical research be the subjectivity or individual identity. The reason being that any state of consciousness which reveals some kind of knowledge about myself or the world, is posterior to the encounter with the Other. Meeting the Other is, thus, the first step to understanding my identity and the world. Hence, the first premise of a philosophical analysis must be the understanding of the relation with the Other (1961: 54--56, 1974: 174).

Although it is true that Levinas writes often about the Other without any further explanation of what he understands under this term, it must be noted that he does defend a very particular characterization of this notion. According to him, the Other is par excellence feminine; femininity is constitutive of the Other (1984: 145, 1991: 14). By attaching a female character to the Other, he wants to highlight two different sets of features that, in his opinion, are needed to correctly approach the Other. On the one hand, he mentions notions that communicate the 'otherness' of the Other. For example, ambiguity, equivocation, duplicity, make-up, self-effacing presence, and so on. On the other hand, he refers to notions that proclaim the familiarity of the Other. For example, discretion, tenderness, voluptuosity, fecundity, and so on (1961). Of course, this characterization of the Other could not go unnoticed by feminism.

In sum, Levinas emphasizes the priority of the Other, considers it the basis for ethics, and describes it by an appeal to femininity. I would like to mention here two interesting conclusions which follow from these statements. First, the existence of sexual differentiation is, on this account, the necessary condition for morality. For Levinas, sexual contact between a man and a woman will be the paradigmatic experience that bridges the clash between the I and the Other (1991: 64). Second, the formulation of sexual differentiation is the first philosophical premise, from which any other statement derives (1961: 274, 1991: 64). The 
study of sexual division is therefore the central task to make sense of the world.

In the above, we have seen that Levinas links his description of the unexplored side of philosophy with a definition of femininity that casts off rationality. To evaluate this idea, we need to reflect upon his particular definition of femininity and, in parallel, of masculinity. In order to do so, I will examine, next, one of Levinas' most explicit texts about sexual differentiation. The purpose of the analysis is to bring to light the real implications of his discourse and show the extent to which Levinas' metaphorical language is, in fact, meaningloaded.

\section{A patriarchal conceptualization of women}

Levinas's concern in 'And God Created Woman' --- one of his talmudic lectures -- is to make sense of sexual differentiation in human beings. To explain such a differentiation, the author raises the following questions: How should we understand the biblical text, according to which woman is built from the rib that God took from man? Does this religious teaching imply a superiority of the masculine over the feminine? Or, on the contrary, does it allow for the equality between sexes?

Levinas answers these questions by way of defending two different thesis that, in my opinion, are incompatible with each other. The two thesis are as follows. On the one hand, he asserts the equality of woman and man, based on the fact that they both belong to humanity. On the other hand, he asserts the inequality of woman and man, based on the fact that the essential features of each sex imply the superiority of the masculine. Hence, Levinas tells us that woman, considered as a human being, is equal to man; but woman, considered as a sexual being, is subjected to him.

A feminist reading of the text reveals the conceptual keys around which Levinas constructs his arguments. He asks the following: Why did woman come to the world, if before she appeared, man already existed, and therefore, humanity already existed in the world? His answer to this question identifies the appearance of woman with the appearance of sexual differentiation. In this way, woman's being is identified with what is considered as 
her unique or characteristic contribution to humanity: sexuality. Woman is, thus, the sexual being par excellence. According to this supposition, man will not be defined from sexuality, since sexuality is the distinctive mark of the feminine. In other words, man can never be reduced to represent or embody the sexual being. ${ }^{3}$

Now, Levinas assumes that sexuality is a secondary aspect in human beings, since it is not what allows them to fully develop themselves as human beings. The immediate conclusion is that woman as woman or, in other words, woman as embodying the sexual being, is secondary in relation to man. Through this argument Levinas explains the meaning of the inequality and the subordination of sexes, while, at the same time, he justifies them. In the following pages, we will see in more detail Levinas' treatment of the 'feminine question'.

\subsection{Equality or hierarchy of sexes?}

Levinas explains the significance of sexual difference through an interpretation of the biblical birth of woman from man. He focusses his attention on the second story of Genesis: 'And God built into a woman "the rib which he had taken from man" (Genesis 2: 22)' (1977: 161). To explain this sentence, Levinas follows the thread of a discussion maintained by two talmudic commentators about its meaning, and states that both commentators agree that woman is human from the beginning: 'The fact that a woman is not merely the female of man, that she belongs to that which is human, is an assumption shared by both disputants: woman is, from the first, created from that which is human' (1977: 169).

At first glance, even if one does not understand very well why an explanation concerning the origin of woman is needed, one feels pleased because it is accepted that woman derives from what is human, rather than from man. Shortly afterwards, however, one would like to know the reasons which made the commentators, and particularly Levinas, be so sure that woman derives from the human, since nothing in the original Genesis text reveals that fact. As it is known, the original text, at least in its translation to modern languages, speaks about the rib taken from man, and not about any rib taken from the human. Since 'man' clearly refers to 'male' here, the key question is the following: does the male by 
himself represent the human? Or more exactly said: do the commentators and Levinas wish to say that the male being already contains by himself every feature proper of humanity? It is clear that only such identification of male with humanity would allow them to hold that, when Genesis says that woman comes from man, it is really saying that she comes from what is human. In any case, there is no doubt about Levinas' identification of the masculine with the human in the following sentence: 'Woman was born from a minor joint of man or of the human being' (1977: 170). Otherwise, how can the introduction of the word or be explained, but as identifying 'man', that is, 'male being', with 'human being'?

At this point, we are able to describe in more detail the commentators' and Levinas' line of thought. The reason why they defend that woman is also a human being, is that she was created from what was already human. At the same time we are told that the first creature was a man, and that woman comes from him. From these two premises we can derive only a consequence, namely, that the human feature is transmitted by man to woman. And hence, coming from a male body part is already coming from what is human. Of course, it is just incorrect to identify the existence of man with the existence of humanity, as if woman were not necessary for humanity to enter into the world, and as if the features she introduces --- according to Levinas, each sex has essential features --- were not necessary for the existence of humanity. ${ }^{4}$

\subsection{Identification of woman with sexuality}

The identification that I have pointed out above between 'male being' and 'human being' turns the creation of woman into something superfluous. To accept that man can transmit the human feature, means that humanity was already possible before woman came to existence. If woman was not needed for humanity to appear, why, then, was she created? Levinas still needs to explain what does the appearance of feminine features add to the world. His answer to this question comes within the context of his interpretation of the talmudic commentators' discussion about the significance of the word 'rib'.

Levinas reminds us that for one of the commentators, 'rib' means 'face', while for the 
other, it means 'tail' and he explains these metaphors to us in the following way. The first talmudic commentator considers sexual differentiation as essential to being human. The feminine and the masculine are two sides that complement each other to build what is human. This position will be rejected by the second talmudic commentator, the one that finally wins the discussion, and whose point of view our philosopher surprisingly defends. The reason given by Levinas to reject that sexual differentiation is essential to human beings, is the following: 'They [human beings] have other things to do besides cooing, and, moreover, something else to do and more, than to limit themselves to the relations that are established because of the differences in sex' (1977: 169).

In my opinion, this reasoning is not valid for the following reasons. By connecting sexual differentiation --- that is, the existence of males and females as different beings --with sexual relations between them, Levinas reduces the function of sexual differentiation to sexual intercourse. That is, he considers that the distinction in human beings between females and males is an issue linked exclusively with sexual relations. Furthermore, such reasoning considers that sexual relations are exclusively held by heterosexual partners. Thus, sexual differentiation would have the only purpose of making heterosexual relations possible. The description of sexuality as a question of mere 'cooing', reveals a very limited conceptualization of what sexuality represents in human relations.

We have seen that the position defended by the second commentator is one which Levinas defends as well. In what follows, I will try to bring to light the unfortunate implications of this position. Since the second position is opposed to the first one --- which defended that sexual differentiation is essential to human beings --- it would seem logical that it maintain that sexual differentiation is secondary, for both men and woman have other things to do besides cooing. Unfortunately, Levinas' text says something rather different: 'It is the relationship with woman which is secondary; it is the relationship with woman as woman that does not belong to what is fundamentally human' (1977: 169).

Levinas' introduction in the last quote of the expression woman as woman leaves no doubt about the conceptual link between woman and sexuality. Of course, he makes no 
allusion to man as man, that is, to man as 'sexual being'. Levinas moves in the same ground as most of western intellectual tradition: a male being is always something more than simply a mere sexual being. In contrast, woman always appears when speaking about sexuality, and monopolizes this field. Now that we understand how Levinas and the talmudic commentators interpret the creation of the woman, we can obtain the answer to our previous question about the reason for her late birth from man: woman was not necessary to bring humanity into the world, for man was already there. In fact, the only function of her creation was to bring sexuality into the world. Sexuality is, thus, basically, woman's essence.

\subsection{Human development: men's versus woman's}

The first answer to the question about the meaning of the existence of woman in the world, which refers to sexuality, is closely linked with another reference directly related to it: it was never good for man to be alone. Again, woman does not come into the world to bring humanity, since this feature was satisfied with the presence of man, but she comes to make man's life more pleasant (1977: 169). We see clearly this time that woman's life does not have any value by itself, but as a means for man to achieve his 'valuable' and 'universal' projects. Woman's role is to be a mere mediator between man and his interests, and hence the existence of woman is justified by man because it allows him to become free. One even has the feeling that woman should thank man's opinion of her.

After all, we will not be taken by surprise when Levinas concludes that sexual liberation is not the adequate path for the spiritual development of the human species (1977: 170). But what reason has Levinas to say that sexual liberation is not the goal of human liberation? The answer is, once again, that women and men have important tasks to do, besides cooing. In my opinion, however, this reasoning is incomplete, for it interprets sexual liberation in an narrow way, as exclusively concerned with romantic relations. Actually, sexual liberation affects not only sexual relationships, but a wide variety of behaviours and conceptual fields. In this sense, sexual liberation cannot be reduced to bed issues, and does have more importance than what Levinas concedes it. Particularly, sexual liberation is linked 
with women's struggle for equality, and from this perspective, it plays a key role in achieving better life conditions for women, as well as for men.

The issue of sexual liberation leads us to another topic connected to it: Levinas' belief in sexuality as a secondary element for the development of what is properly human in us. In other words, his belief that the sexual field is not the real human field (1977: 172). In this sense, Levinas' discourse reveals certain identifications too common in the history of ideas, and which have encouraged women's oppression. I am referring to equations such as: spiritual $=$ high, nature $=$ low. It is unacceptable to forget that the notions of 'sexuality', 'nature', 'inferior' and 'femininity' have often been conceptually related, and that they have often been opposed to notions like 'spiritual', 'human', 'elevated' and 'masculinity'. The kind of conceptual associations mentioned by Levinas are meaning-loaded, specially in the context of a reflection about woman. In fact, these associations are not ignored by Levinas, since only who accepts them, promotes them. In short, this quotation can easily be read as the old traditional advice to man that his spiritual development will not come from his relation to woman. The old myth comes to our minds: woman as the fatal attraction for man, which he should avoid.

The above analysis strengthens our opinion that, what Levinas seemed to be defending at the beginning, that is, an ideal of equality between sexes, ends being just that: an ideal. We can now see clearly that the task Levinas wanted to accomplish, is paradoxical from a logical point of view. On the one hand, Levinas wants to defend that woman, as a human being, is equal to man; on the other, he wants to defend that woman, 'as a woman', that is, as possessing a sexual feature, is not equal to man, but subordinated to him. I have tried to show that it is contradictory to sustain both theses at the same time, since the subordination of woman 'as woman' --- using Levinas' words --- brings with it the subordination of real woman in her actual life in society. Levinas' theoretical strategy justifies the subordination of women to men, since it implies, in practice, forgetting the first thesis in favor of the second. In effect, what is the point of being considered equal to men, if in every field of her life where she expresses herself as a sexual being --- that is, in every 
aspect of her everyday, social and political life --- she is considered to be subordinate to male? Levinas' position can be very easily summed up: the defence of the subjection of woman in practice behind the supposed abstract defence of the equality thesis.

We still need to mention another old battle: the identification of the feminine with the apparent, the non-real. Levinas does not hesitate to present us with an example of the equation between woman and illusion: 'In the feminine, there is face and appearance. He [God] created the first illusions, the first make up. To build a feminine being is from the outset to make room for appearance' (1977: 174). Throughout history, men have conceptualized the essence of the second sex as a mere appearance. By way of contrast, the essence of the first sex was understood as real, as being neither a mere illusion nor an appearance. Men were the ones who theorized, established the definitions of objects, and named them. They saw themselves as the unique truthful essences, while the others --- that is, women--- occupied the dark side of being, the fictitious, the non-trustworthy. In this way, a dualism of important negative repercussions for women was established. Once woman is defined as a mere appearance, the priority of the masculine goes without saying.

Later on, we can find Levinas' open defence of the leadership of man: the necessity of inequality to preserve functionality, the inevitable connection between femininity and eroticism, the prudent advice to man to keep apart from woman if he aspires to have clear and important thoughts (1977: 174). Strange as it may seem, the male right to lead is maintained, even in those cases where woman has good ideas about what needs to be done. Even if she knows the direction, she must let herself be guided by man. Under these premises, on which basis can we still believe that Levinas supports the equality between man and woman, as he said at the beginning?

The final paragraph of Levinas's text contains a dangerous conceptual snare, since it confuses descriptive and prescriptive aspects (1977: 175). Levinas describes the fact that man has historically achieved a certain elevation sooner than woman. Such description needs, however, a further explanation so as not to confuse the reader. The description of the higher 'elevation' of male is correct if elevation is understood as a higher capacity to actually 
execute his individuality, and a higher actual respect for his rights. But for this description to be just, it is necessary to say that women could not have achieved the same peaks of civilization along history, not due to a lack of capacities or essential reasons, but because they were submitted to a continuous historical oppression by males. It is a very serious error that Levinas interprets the historical situation of masculine privilege, not as an abuse of power, but as a deserved and just condition.

Thus, to treat the question of sexual hierarchy, Levinas considers the description of the features that belong to each sex. He then tries to answer the following two questions: Which features define each sex? How do these features affect the relation between males and females? Levinas' answers to these questions show that, despite what he said before regarding the equality of females and males as human beings, he justifies a difference in status as to the rights and behaviors that are proper of each sex. Obviously, the conjunction of both thesis not only gives rise to a problem of incoherence from a logical point of view, but it is unacceptable from an ethical perspective.

\section{Levinas' reception within feminism}

A branch of feminism has recently defended that Levinas' reading of sexual difference combines, in a most paradoxical way, a radical new way of thinking with a rather traditional conception of 'woman' and sexual difference. These authors recall that he viewed his theory as a very critical reading of the male western thinking which excludes the Other and reduces everything to the order of the One and the Same. They further emphasize his proposal of developing a completely different way of thinking, written almost completely from the perspective of the Other, a way of thinking he himself calls 'feminine'.

According to this approach, Levinas could very well serve the purposes of feminism. An important question for feminist philosophers reading of Levinas is therefore the following: although Levinas conceptualizes a traditional patriarchal notion of 'woman' and femininity, his way of thinking itself might be a profound and radical critique of western, patriarchal thinking itself. Couldn't we explain Levinas more or less traditional concept of 
sexual difference with reference to the sociological or historical circumstances of his time, and concentrate instead on the radical impact of his thinking of otherness? In other words, shouldn't we explore in what way Levinas thinking can inspire us with the development of a feminist thinking of alterity, relation I--Other, plurality, and transcendence of identity, for example? My answer to this question is: No, I do not think that Levinas' account of the Other and the feminine can be of any help for feminism.

The thesis of the essentiality of sexual features, that is, the thesis that people are marked by certain features --- in behaviour, personality, social role, and so on --- due to their sex is, at the very least, a polemic thesis. The discussion around essentialism has divided positions in the field of feminist theory, and is still an open and burning debate. We could distinguish two points of view:

Firstly, some feminists defend the existence of a feminine identity, and base their position on biological or cultural essentialist theories. They support the right (of women) to be different (from men), and believe that a feminine identity will lead to an end of patriarchy. Secondly, some other feminists consider speaking of a singular identity of 'woman' or of women problematic, though their reasons vary. Some argue that hetero-designation --- or how men define women --- has often been simplistic and dogmatic, and has sustained the existence of a female identity where there was none; others ask to what extent the supposed essence is independent of the cultural or historical contexts. In any case, they all support the right (of women) to be equal (to men), and believe that the only way to overcome patriarchy is by erasing those distinctions between sexes that justify women's discrimination. These two positions have been labeled, respectively, feminism of difference and feminism of equality. ${ }^{5}$

In what follows, I will argue in favour of feminism of equality by dealing with the recent reception of Levinas' theory by some feminists of difference. Supporters of feminism of difference often maintain that most philosophical views about what it means to be human have been shaped by a masculine bias, so that what has usually been identified as human features were, in fact, features that only men possessed, even more, that only they could possess. They believe that being a woman is something different than being a man, and hope 
to find a view that specifically describes what it is to be a woman. Hence, they find interesting Levinas' endeavor to contest masculine history of ideas, and share his opinion that women's features are different and need to be brought to light.

Now, when trying to correct the masculine biased perspective on the notion of humanity that the history of ideas has left to us, feminists of difference proceed according to the following strategy. Instead of correcting those masculine biased perspectives by expanding the reference of certain terms to include women, they deny that these terms are appropriate to them, and demand that different terms --- which would supposedly characterize women --- be included in the definition of humanity. An example may clarify this point. Levinas accuses the history of philosophy of being centered around the notion of logos. For him, reason is the realm of the masculine, so that it is a masculine bias to define the human being as a rational being. The Other --- that is, the feminine --- is not governed by reason. Well, how does feminism of difference react to these statements? It does not refute Levinas by claiming that women are also rational; rather it agrees with him in that reason is a masculine feature, and chooses for femininity the realm of a-rationality. I do not agree with them in that this strategy be at all useful for women.

Of course, the equation woman = the Other is nothing new in the history of ideas and, as many studies have shown, we find it from Pythagoras on. It would be easy to prove, however, that such a heterodesignation by men brought nothing but troubles for women. ${ }^{6}$ Now, what is new in the history of ideas, is the conceptual move that the feminism of difference performs, namely, the autodesignation by women of the realm of the Other as a means to improve women's situation.

In my opinion, feminism must take extreme care when facing any proclamation of male's essence as different of female's essence. The distinction of sexual identities can be a dangerous conceptual trick, if one really wants to defend that both men and women belong, with equal rights, to the human race. Every differentiation implies the definition of each part. It is true that, from a strictly logical point of view, a differentiation does not necessarily imply a specific judgement of value of the qualities of each part --- that is, the claim that the 
features of one of the sexes are better than of the other. In practice, however, it is a fact that a judgement of value arises. Therefore, the result of the differentiation ends up being a judgment of value about which of the two essences is superior, and, curiously, the qualities of 'woman' receive systematically the worst evaluation. We could mention thousands of examples, but let us just remember one included in Levinas' text: the initial claim that masculine qualities are more appropriate for public life and that feminine qualities are more appropriate for private life, is followed by the defence that public life is the field where human beings can develop those qualities that are really proper of them.

Of course, when feminists of difference hold that certain features are properly feminine, they do not want to label them as inferior. But, that is precisely the problem. It does not matter so much what they want but what it is actually achieved through their strategy. They would like to change the meaning of certain terms by provinding them with a neutral or a positive connotation that they traditionally lacked. It seems to me that this strategy is doomed to end in failure because the social signification of terms cannot be easily changed at will. Whether a certain language can be re-signified does not depend only upon voluntarism, but upon the very possibilities of re-signification that the language contains. Let me illustrate this with an example.

After the French Revolution, feminists denounced that only men were considered full citizens, and vindicated, using rational arguments, the status of citizenship for women. At the beginning, the use of the term 'citizen' for women sounded strange to many ears. Many years after, however, the widening of its reference had achieved linguistic credit. To explain the conceptual change, it is not enough to point at the collective will of the feminists. No doubt, they wanted to be called citizens and they started calling themselves citizens; but the key question was, how could they convince their opponents that their use of language was legitimate? Obviously, in order to be efficient in their claims they needed to implement a strategy that could go beyond their mere wishes. And they chose a good one: they used the very language of the Enlightenment to challenge the acceptability of their own segregation. That is, they appealed to the same reasoning that male revolutionaries used to abolish the Old 
Regime. Feminists clung to the argument that no human being was to be excluded from citizenship because of the social status determined by birth. They then claimed that women should not be excluded from citizenship, since their sexual character is also a product of birth. As this example shows, the kind of re-significations made possible by Enlightened feminists depended not only upon their desires, but upon rational arguments that showed the incoherences of certain restrictive interpretations of the terms. The Enlightened discourse was based on a universalizing ideal, and feminism took advantage of it. ${ }^{7}$

This strategy contrasts with the appropriation of Levinas by some feminists of difference. For these feminists do not aspire to irrationalize the hierarchical distinctions between terms, but to be indifferent to the asymmetrical connotations implied by the social use of the terms. They believe that it is possible to ignore the actual meaning of traditional heterodesignations, and re-signify them, to a certain extent, at will. In my opinion, though, that path leads to a dead end. The only way to step forward in the liberation of women is to use rational arguments against certain social and linguistic situations that impeded the full resignification of terms, avoiding strategies that have historically proved inefficient.

In short, Levinas' general treatment of the differentiation of human beings into sexual beings assumes an essentialist position, according to which there is something like 'woman' or the feminine essence. My disagreement with Levinas and those who support his approach to these issues, is that their non-critical consideration that certain features are proper of each sex and determine its social role, does in practice imply and justify the inequality of women. In fact, those features that Levinas and feminism of difference regard as proper of each sex, are exactly the same features that have traditionally been sustained to subordinate women. Therefore, to continue to defend them in the last third of the twentieth century contributes nothing to solve the situation.

Thus far, I have argued that Levinas' identification of 'woman' with the Other cannot serve the purposes of feminism.

\section{Conclusion}


No doubt, Levinas' thesis that the study of sexual differentiation must be the first task of philosophy, is interesting from a feminist point of view. In fact, we can read this statement as being equivalent to the general feminist claim that considering sexual issues is crucial for any interpretation of human activities along history and across societies. I fully agree in that any attempt to make sense of the world and to pose ethical, epistemological or aesthetical conclusions comes after studying sexual division and agreeing on a certain characterization of what it means and implies. However, I do not think that Levinas' beneficial effects for feminism could exceed this point.

\section{Endnotes}

(1) I would like to thank the following people for their help: Ángeles J. Perona, Teresa Padilla, Celia Valiente, Óscar González Castán y Cèlia Amorós. Jerelyn Johnson y Dominic Lawn reviewed the English version.

(2) The text "And God created Woman" was a lecture held by Levinas on the 16th of October of 1972 in Paris, in the context of the Colloquia of Jewish Intellectuals in France. The general title of the colloquium was 'Ish et Ishá' or 'the Other par Excellence', and the proceedings were published in L'autre dans la conscience juive: Le sacré et le couple: Données et débats, Paris: PUF, 1973. The text was later included in Levinas (1977).

(3) About the identification of woman with sexuality in contemporary philosophy, cf. Puleo (1992).

(4) The assimilation between 'male' and 'what is human' is the ideological knot of the patriarchy that feminism tries to undo. For a critique of such an equation from the perspective of feminism of equality, cf. Amorós (1997b).

(5) A follow-up to the debate between feminism of difference and feminism of equality can be found in Sottosopra (1996) and in the answer to this manifest by Amorós (1996). For further arguments about these three positions, cf. Benhabib et al. (1995).

(6) About treating women as 'the Other' by excellence and its consequences for women, cf. 
Beauvoir (1949).

(7) On the peculiarities of the language employed by women when they formulate their vindications, cf. Amorós (1997a)

\section{Bibliography}

Ainley, Alison (1988) 'Amorous Discourses: "The Phenomenology of Eros" and Love Stories', pp. 70--82 in R. Bernasconi and D. Wood (eds) The Provocation of Levinas. London: Routledge.

Amorós, C. (1997a) 'Richard Rorty and the "Tricoteuses"', Constellations 3 (3): 364-376.

Amorós, Celia (1997b) Tiempo de Feminismo. Sobre feminismo, proyecto ilustrado y postmodernidad. Madrid: Cátedra.

Amorós, C. (ed) (1995) Diez palabras sobre mujer. Navarra: Verbo Divino.

Amorós, C. (1996) 'La política, las mujeres y lo iniciático', El Viejo Topo, (Madrid), noviembre.

Beauvoir, Simone de (1949) Le deuxième sexe, Paris: Gallimard. There is an English translation: The Second Sex. New York: Random House, 1974.

Benhabib, Seyla, Judith Butler, Drucilla Cornell and Nancy Fraser (1995) Feminist Contentions. London: Routledge.

Bock, Gisela and Susan James (eds) (1992) Beyond Equality and Difference. Citizenship, Feminist Politics and Female Subjectivity. Londres: Routledge.

Chalier, Catherine (1982) Figures du feminin: Lecture d'Emmanuel Levinas. Paris: La Nuit Surveillée.

Chanter, T. (1988) 'Feminism and the Other', pp. 32--56 in R. Bernasconi and D. Wood (eds) The Provocation of Levinas. London: Routledge.

Chanter, Tina (1995) The Ethics of Eros. Irigaray's Rewriting of the Philosophers. London.

Fraisse, Geneviève (1992) 'Provenances de la pensée', Les cahiers du Grif, 46, Paris: DeuxTemps-Tierce.

Levinas, Emmanuel (1961) Totalité et infini: essai sur l'extériorité. The Hague: Nijhoff. 
[English translation: Totality and Infinity: an Essay on Exteriority. Pittsburgh:

Duquenesque University Press, 1969.]

Levinas, E. (1974) En découvrant l'existence avec Husserl et Heidegger. Paris: Vrin.

Levinas, E. (1977) Du Sacré au saint. Cinq nouvelles lectures talmudiques. Quatrième

leçon: Et Dieu créa la femme. Paris: Editions de Minuit. [English translation: Nine

Talmudic Readings. Bloomington: Indiana University Press, 1990.]

Levinas, E. (1984) De l'existence à l'existant. Paris: Vrin. [English translation: Existence and

Existents. The Hague: Nijhoff, 1978.]

Levinas, E. (1991) Le Temps et l'autre. Paris: Presses Universitaires de France.

O'Connor, Noreen (1988) 'The Personal is Political: Discursive Practice of the Face--to--

Face', pp. 57--69 in R. Bernasconi and D. Wood (eds) The Provocation of Levinas.

London: Routledge.

Puleo, Alicia (1992) Dialéctica de la sexualidad. Madrid: Cátedra.

Sottosopra/Librería de Mujeres de Milán (1996): 'El final del patriarcado', El Viejo Topo,

(Madrid), junio. 